\title{
Differences in the plasma concentrations of FSH and LH in ovariectomized Booroola FF and ++ ewes
}

\author{
K. P. McNatty, M. Fisher, F. Collins, N. L. Hudson, D. A. Heath, K. Ball \\ and K. M. Henderson
}

Wallaceville Animal Research Centre, MAFTech, Ministry of Agriculture and Fisheries, P.O. Box 40063, Upper Hutt, New Zealand

\begin{abstract}
Summary. During 12 sampling days before ovariectomy the mean plasma FSH but not LH concentrations in FF ewes were higher $(P<0.01)$ than those in ++ ewes $(16$ ewes/genotype). After ovariectomy increases in the concentrations of FSH and $\mathrm{LH}$ were noted for ewes of both genotypes within 3-4 h and the rates of increase of FSH and $\mathrm{LH}$ were $0.18 \mathrm{ng} \mathrm{ml}^{-1} \mathrm{~h}^{-1}$ and $0.09 \mathrm{ng} \mathrm{ml}^{-1} \mathrm{~h}^{-1}$ respectively for the first $15 \mathrm{~h}$. From Days 1 to 12 after ovariectomy, the overall mean \pm s.e.m. concentrations for FSH in the FF and ++ ewes were $8 \cdot 1 \pm 0.6$ and $7 \cdot 1 \pm 0.4 \mathrm{ng} / \mathrm{ml}$ respectively and for LH they were $2.7 \pm 0.3$ and $2.1 \pm 0.2 \mathrm{ng} / \mathrm{ml}$ : these differences were not statistically significant ( $P=0.09$ for both FSH and LH; Student's $t$ test). However, when the frequencies of high FSH or LH values after ovariectomy were compared with respect to genotype over time, significant $\mathrm{F}$ gene-specific differences were noted $(P<0.01$ for both FSH and LH; median test).

In Exp. 2 another 21 ewes/genotype were blood sampled every 2nd day from Days 2 to 60 after ovariectomy and the plasma concentrations of FSH and $\mathrm{LH}$ were more frequently higher in FF than in ++ ewes $(P<0.01$ for FSH and $\mathrm{LH})$. The $\mathrm{F}$ genespecific differences in $\mathrm{LH}$ concentration, observed at 21-36 days after ovariectomy were due to higher mean $\mathrm{LH}$ amplitudes $(P<0.025)$ but not $\mathrm{LH}$ peak frequency in $\mathrm{FF}$ than in ++ ewes.

Collectively the evidence shows that the greater frequency of high plasma gonadotrophin concentrations in FF compared to ++ Booroola ewes occurs independently of ovarian hormones and that the principal site(s) of $\mathrm{F}$ gene expression may not be in the gonad.
\end{abstract}

Keywords: Booroola ewes; ovariectomy; plasma FSH; plasma LH

\section{Introduction}

High fecundity Booroola ewes contain a major gene(s) (F) which influences their ovulation rate (see Bindon, 1984, for review). Homozygous $(F F)$, heterozygous $(F+)$ and non-carriers $(++)$ of the putative gene(s) are segregated on the basis of ovulation rate recordings of $\geqslant 5,3$ or 4 and 1 or 2 respectively (Davis et al., 1982). Previous studies have demonstrated differences both in ovarian activity and plasma gonadotrophin concentrations between ++ and FF ewes (see McNatty \& Henderson, 1987 for review). With regard to the gonadotrophins, follicle-stimulating hormone (FSH) and luteinizing hormone ( $\mathrm{LH})$, the mean plasma concentrations were shown to be significantly higher in FF than in ++ ewes, with those of $F+$ animals being consistently in between. Despite these differences, it is not known whether the principal sites of $F$ gene expression are in the pituitary, ovary or elsewhere. The aim of this study was to examine whether the $F$ gene-specific differences in plasma gonadotrophin concentrations persisted after ovariectomy. 


\section{Materials and Methods}

\section{Animals and experiments}

Booroola Merino ewes born in 1978-80 were classified as being of the $++(\mathrm{N}=37)$ or $\mathrm{FF}(\mathrm{N}=37)$ genotypes based on pedigree analysis and were confirmed by laparoscopy according to the criteria of Davis et al. (1982). All the FF ewes, aged 6-7 years at the time of the study, were recorded as having at least one annual ovulation rate of $\geqslant 5$ whereas the ++ ewes were never recorded as having an ovulation rate of $>2$.

Experiment 1 was designed to examine the daily plasma concentrations of FSH and LH from 12 days before until 12 days after ovariectomy (day of ovariectomy = Day 0 ) in $16 \mathrm{FF}$ and $16++$ ewes. In addition to the daily blood samplings, hourly samples were collected from $26 \mathrm{~h}$ before to $36 \mathrm{~h}$ after ovariectomy to examine in more detail the changes in hormone concentrations shortly before and after removal of the ovaries. The mean \pm s.e.m. day of the oestrous cycle when ovariectomy was performed was $7.8 \pm 0.5$ and $7.6 \pm 0.5$ for sheep of the FF and ++ genotypes respectively. The ovaries were removed surgically, after the animals had been anaesthetized. Thiopentone was used to induce anaesthesia which was maintained using halothane (Fluothane: Coopers Animal Health, Upper Hutt, New Zealand). The whole surgical procedure from induction of anaesthesia to cessation of halothane administration was $20 \mathrm{~min}$. At ovariectomy, the number of corpora lutea $(\mathrm{CL})$ in each ovary was recorded. On the day before the hourly blood sampling was due to be started the animals were penned indoors and each was fitted with an intrajugular cannula. For the once hourly collections $2.5 \mathrm{ml}$ blood were collected via the jugular cannulae. The blood sample at $0 \mathrm{~h}$ was taken during thiopentone treatment and that at $1 \mathrm{~h}$ was taken while the animals were recovering from the effects of anaesthesia. At $2 \mathrm{~h}$ after induction of anaesthesia the animals were standing and some were eating. For the once daily collections $5 \mathrm{ml}$ blood were collected from the jugular vein into a heparinized vacutainer.

Experiment 2 was designed to examine the plasma concentrations of FSH and LH every 2 nd day from 2 to 60 days after ovariectomy (Day 0 ) in a second set of $21 \mathrm{FF}$ and $21++$ ewes. The numbers of CL in each ovary were recorded at ovariectomy which was performed as described in Exp. 1 . On each sampling day, a blood sample (5 ml) from each ewe was collected from the jugular vein into heparinized vacutainers. At 21-36 days after ovariectomy, the animals were brought indoors and each was fitted with an intrajugular cannula. The following day, each animal was bled $(2.5 \mathrm{ml})$ via the jugular cannula once every $10 \mathrm{~min}$ for $12 \mathrm{~h}$ to determine the pulsatile characteristics of the plasma $\mathrm{LH}$ concentrations.

All blood samples were centrifuged at $4000 \mathrm{~g}$ at room temperature for $8 \mathrm{~min}$ within $30 \mathrm{~min}$ of collection and the plasma samples were stored at $-20^{\circ} \mathrm{C}$ until assayed.

\section{Hormone assays}

FSH. The radioimmunoassay kit was that supplied by The National Institute of Arthritis, Metabolism and Digestive Diseases (NIAMDD), Bethesda, MD, USA. The ovine (o) FSH for iodination was NIAMDD-oFSH-I-1; the oFSH reference preparation was NIAMDD-oFSH-RP-1 (biopotency $75 \times$ NIH-FSH-3) and the oFSH antiserum was NIAMDD-anti oFSH-1 (AFP-C52881 13). At a final FSH antiserum dilution of 1:80 000 this homologous assay had a working range of 0.01 to $5 \mathrm{ng}$ per assay tube. The volume of plasma which was assayed was $0.1 \mathrm{ml}$ and each sample was assayed in duplicate. The reference standards and standard curve samples were prepared in hypophysectomized ewe plasma which contained undetectable concentrations of FSH. The intra- and interassay coefficients of variation were $<4$ and $<5 \%$ respectively.

$L H$. The radioimmunoassay was similar to that described by McNatty et al. (1987). The iodination standard was NIDDK-oLH-I-3 (AFP-9598B), the oLH reference preparation was NIAMDD-oLH-S23 (biopotency $2.3 \times$ NIHLH-S1) and the LH antiserum was raised at Wallaceville (characteristics were as described by McNatty $e t$ al., 1987). The volume of plasma which was assayed was $0.1 \mathrm{ml}$ and each sample was assayed in duplicate. The minimum detectable concentration of $\mathrm{LH}$ was $0.03 \mathrm{ng} /$ tube. The reference standards and standard curve samples were prepared in hypophysectomized ewe plasma which contained undetectable amounts of LH. The intra- and interassay coefficients of variation were $<5$ and $<8 \%$ respectively.

\section{Statistical analysis}

For each genotype separately, the plasma LH or FSH concentrations in each daily or hourly period showed no major departures from normality when assessed by the Shapiro-Wilk test (Zar, 1974). The variance in the FF genotype was significantly higher than that in the ++ genotype using Bartlett's test and so the Student's $t$ test with the Satterthwaite approximation (Snedecor \& Cochran, 1980) was used for genotypic comparisons within each time. This $t$ test was also used for overall genotype differences. Box and whisker plots (Velleman \& Hoaglin, 1981) were used to show the distribution of these overall means within each genotype. For each genotype sample correlations were performed at various times to test whether the FSH or LH concentrations in the ewes remained in the same order over time.

Partial autocorrelations for each sheep over time were calculated so that the relationship between times could be investigated. These were not found to be significant for most sheep and so the median test was used to see whether there were genotypic differences in the proportions of high values after adjusting for time differences (Conover, 1971). 
Within each genotype, although there was some heterogeneity of variance between times, the effects of time were examined by analysis of variance.

The episodic LH data were examined using the method of Van Look (1976). A pulse was defined as occurring when the hormone concentrations of 2 consecutive samples were greater than that of the mean of the 2 previous samples (basal samples) and the value of at least one of the peak samples exceeded the mean basal value by more than twice the coefficient of variation of the assay which was set at $8 \%$. The amplitude of each pulse was measured by subtracting the basal value from the peak value. The 'smoothed' mean value was defined as the overall mean basal value after all peak values were removed. Genotype differences in episodic LH data were compared by Student's $t$ test.

\section{Results}

\section{Plasma FSH and LH concentrations before and after ovariectomy (Exp. 1)}

The daily mean \pm s.e.m. plasma concentrations of FSH and $\mathrm{LH}$ for each genotype from 12 days before until 12 days after ovariectomy are summarized in Fig. 1.

The mean \pm s.e.m. ovulation rates as judged by the number of $C L$ in the ovaries at ovariectomy (time 0 h; Fig. 1) were $5.8 \pm 0.3(N=16)$ for the FF ewes and $1 \cdot 8 \pm 0 \cdot 1(N=16)$ for the ++ ewes.

Before ovariectomy, the daily mean concentrations of FSH but not LH were consistently higher in FF than in ++ ewes. Significant differences $(P<0 \cdot 05)$ for FSH were observed on 9 of the 13 sampling days (i.e. Days $-10,-9,-6,-5,-4,-3,-2,-1$ and 0 ) whereas none was observed for LH. The mean \pm s.e.m. FSH concentrations of ewes of the FF genotype were significantly higher than those of the ++ genotype when the values for each sheep were averaged over time $(P<0.001 ; \mathrm{FF}, 1.7 \pm 0.1 \mathrm{ng} / \mathrm{ml} ;++, 1.1 \pm 0.1 \mathrm{ng} / \mathrm{ml})$. The corresponding mean \pm s.e.m. $\mathrm{LH}$ concentrations in sheep of the FF and ++ genotypes were $0.32 \pm 0.05$ and $0.33 \pm 0.05 \mathrm{ng} / \mathrm{ml}$ respectively. After ovariectomy, the concentrations of FSH and LH in both genotypes began to increase some $3 \mathrm{~h}$ later (Fig. 1). Thereafter there was a steady increase in the daily FSH and LH concentrations for 5-6 days and 2 days respectively after which the concentrations for both hormones remained relatively constant until 12 days after ovariectomy (the last day of blood sampling). Regression analysis of the mean FSH (1) and LH (2) concentrations during the first $15 \mathrm{~h}$ after ovariectomy for ewes of each genotype gave the following equations: (1) for FF ewes, $y=0 \cdot 18 x+1.84(r=0 \cdot 974 ; 15 \mathrm{df})$, and for ++ ewes, $y=0 \cdot 18 x+$ $1.11(r=0.960 ; 15 \mathrm{df})$ where $y=$ plasma FSH concentrations in $\mathrm{ng} / \mathrm{ml}$ and $x=$ time in hours; (2) for FF ewes $y=0.09 x+0.18(r=0.930 ; 15 \mathrm{df})$ and for ++ ewes, $y=0.09 x+0 \cdot 18(r=$ $0.898 ; 15 \mathrm{df}$ ) where $y=$ plasma LH concentrations in $\mathrm{ng} / \mathrm{ml}$ and $x=$ time in hours. Moreover, over this time frame the mean FSH values in FF ewes were consistently (i.e. $\sim 0.7 \mathrm{ng} / \mathrm{ml}$ ) higher than in the ++ ewes whereas the mean $\mathrm{LH}$ values in ewes of the two genotypes were essentially the same.

After ovariectomy no $\mathrm{F}$ gene-specific differences in mean concentrations were observed on any individual sampling day for either FSH or LH. For FSH from Days +1 to +12 , the overall mean \pm s.e.m. concentrations in the FF and ++ ewes $(N=16 /$ genotype $)$ were $8.1 \pm 0.6$ and $7 \cdot 1 \pm 0.4 \mathrm{ng} / \mathrm{ml}$ respectively and for $\mathrm{LH}$ they were $2 \cdot 7 \pm 0.3$ and $2 \cdot 1 \pm 0.2 \mathrm{ng} / \mathrm{ml}$ respectively. The differences between the overall means were not significant (FF v $++:$ FSH and LH; $P=0.09$ ) but (as shown in the box and whisker plots; Fig. 2) about 3/4 of the FF ewes had mean FSH or LH values above the median of the ++ sheep. The correlation coefficients for the FSH and LH concentrations averaged over Days -12 and $-11,+1$ and +2 or +11 and +12 were not significantly correlated with one another, indicating that the animals with the highest values at any of the above times were not necessarily those with the highest at the other times. When the proportions of high FSH or LH values were compared with respect to genotype over time (by the Median test), significant $\mathrm{F}$ gene-specific differences were noted for both FSH $(P<0.01)$ and LH $(P<0.01) ; 60 \%$ of the FSH and $55 \%$ of the LH values in FF ewes were above the daily overall median values for ewes of both genotypes (192 samples per genotype). 

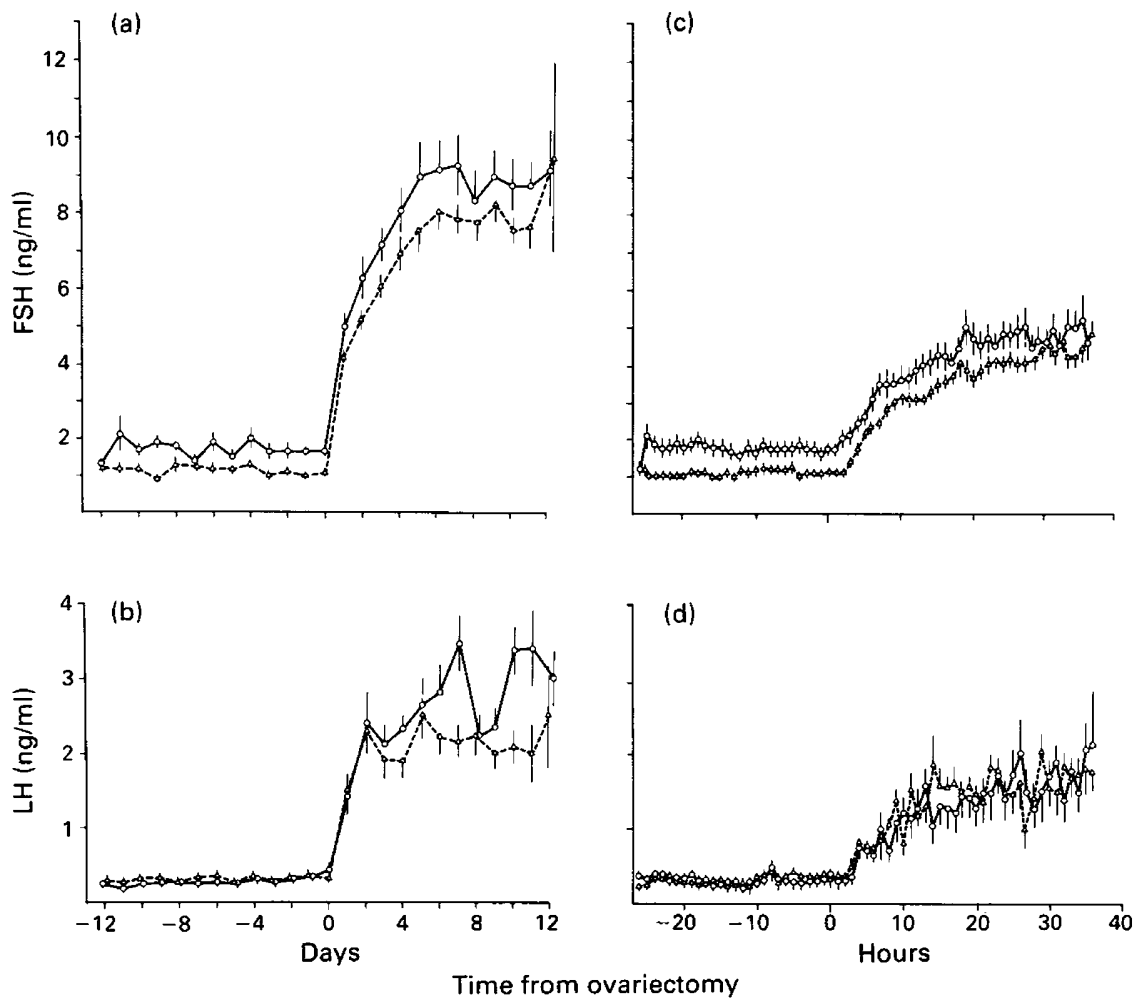

Fig. 1. Changes in the plasma concentrations of FSH and LH measured once daily for 12 days before and after ovariectomy (FSH, la; LH, 1b) and from $26 \mathrm{~h}$ before until $36 \mathrm{~h}$ after ovariectomy (FSH, 1c; $\mathrm{LH}, 1 \mathrm{~d})$ with respect to Booroola genotype (FF, $\mathrm{O}-\mathrm{O}$; ++, $\triangle---\Delta$ ). Ovariectomy was performed within minutes of the blood sample collected at $0 \mathrm{~h}$. Values are means \pm s.e.m. for 16 ewes/genotype.

\section{Plasma concentrations of FSH and LH after ovariectomy (Exp. 2)}

The mean \pm s.e.m. ovulation rates in the $\mathrm{FF}$ and ++ ewes as judged by the number of $\mathrm{CL}$ at ovariectomy were $4.7 \pm 0.2$ and $1.3 \pm 0.1$ respectively.

The mean \pm s.e.m. plasma concentrations of FSH and LH for each genotype from Day +2 to Day +60 after ovariectomy are summarized in Fig. 3 as are the box and whisker plots of the overall mean FSH and LH concentrations over time for each genotype. The mean concentrations of FSH and $\mathrm{LH}$ in both genotypes were variable with time after ovariectomy but overall they increased from $10 \mathrm{ng} / \mathrm{ml}$ and $1 \mathrm{ng} / \mathrm{ml}$ respectively at Day +2 to $16-20 \mathrm{ng} / \mathrm{ml}$ and $2 \mathrm{ng} / \mathrm{ml}$ respectively at Day +60 : for each genotype, the increases in the mean concentrations of FSH and LH were significantly different with respect to time (one-way ANOVA for each genotype separately; $P<0.01$ for both FSH and $\mathrm{LH}$ ). Overall, the variances of the FSH and $\mathrm{LH}$ concentrations for ewes of the FF genotype were $\sim 2-2.5$ times those for the ++ genotype.

When the mean FSH and LH concentrations within each time were compared, significant genespecific differences $(P<0.05)$ were noted for only 3 of the 30 sampling days for FSH (i.e. Days 14, 38 and 50 ) and for only 1 of the 30 sampling days for LH (i.e. Day 30). The mean \pm s.e.m. FSH concentrations over time for ewes of the FF and ++ genotypes (21 ewes/genotype) were $16.0 \pm 1 \cdot 2$ and $12.6 \pm 0.8 \mathrm{ng} / \mathrm{ml}$ respectively. Likewise, the mean \pm s.e.m. LH concentrations for the FF and ++ genotypes were $2 \cdot 2 \pm 0.3$ and $1 \cdot 7 \pm 0.2 \mathrm{ng} / \mathrm{ml}$. For FSH but not $\mathrm{LH}$, the overall 


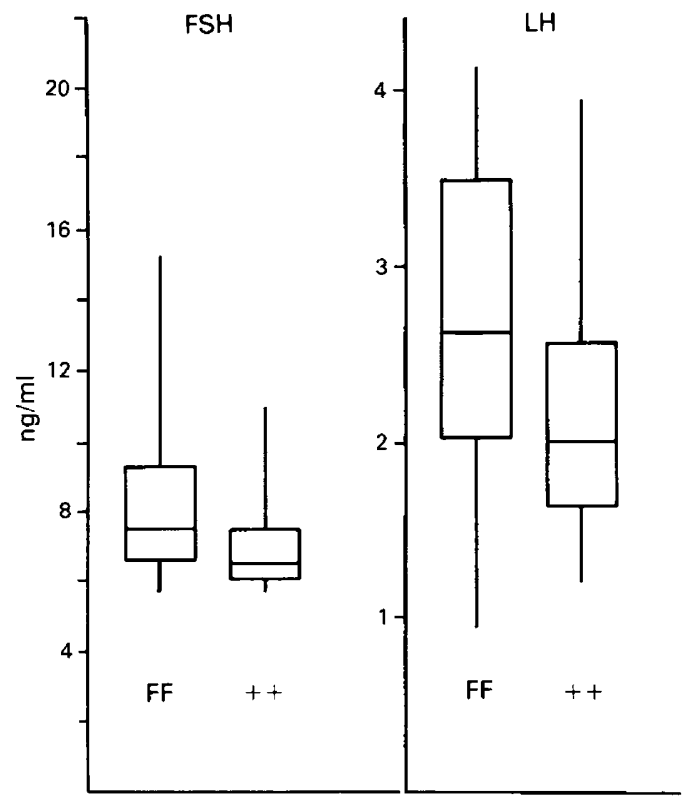

Fig. 2. Box and whisker plots of the mean FSH and LH data for each ewe averaged over 12 days from ovariectomy with respect to genotype. The extreme ends of the vertical (whisker) lines represent the maximum and minimum values. The upper and lower horizontal lines of the box refer to the upper and lower quartiles and the lines through the box represent the median values.

means for the FF ewes were significantly different from those for the ++ ewes $(P<0.02)$. For FSH this difference between the overall means was not due to only 1 or 2 sheep as assessed by sample correlation analysis. From examination of the box and whisker plots, half of the FF ewes had mean FSH values higher than $75 \%$ of the ++ ewes (Fig. 3). For LH, the box and whisker plots showed a similar tendency for more FF ewes to have higher mean concentrations than was the case for the ++ animals. The correlation coefficients for the FSH and LH concentrations averaged over Days 2 and 4 and Days 58 and 60 respectively were not significant, indicating that ewes with the highest FSH or $\mathrm{LH}$ values 2-4 days after ovariectomy were not necessarily the animals with the highest values at Days 58-60 after ovariectomy. When the proportions of high FSH or LH values were compared with respect to genotype over time (by the median test), significant $F$ gene-specific differences were noted for both FSH and LH (FSH: FF $>++; P<0.01$; LH: FF $>++; P<0.01) ; 60 \%$ of the FSH and $58 \%$ of the LH values in ewes of the FF genotype were above the daily overall median values for all sheep (630 samples/genotype).

Pulsatile characteristics of plasma LH concentrations in ovariectomized Booroola ewes with respect to genotype

As summarized in Table 1, there was about $1 \mathrm{LH}$ peak every $75-90 \mathrm{~min}$. No differences were noted in LH peak frequency between the genotypes. However, the LH peak amplitudes were significantly higher in FF compared to ++ ewes $(P<0.025)$ and the smoothed mean LH concentrations were $1 \cdot 3$-fold higher in FF than in ++ ewes $(P<0.05)$. 

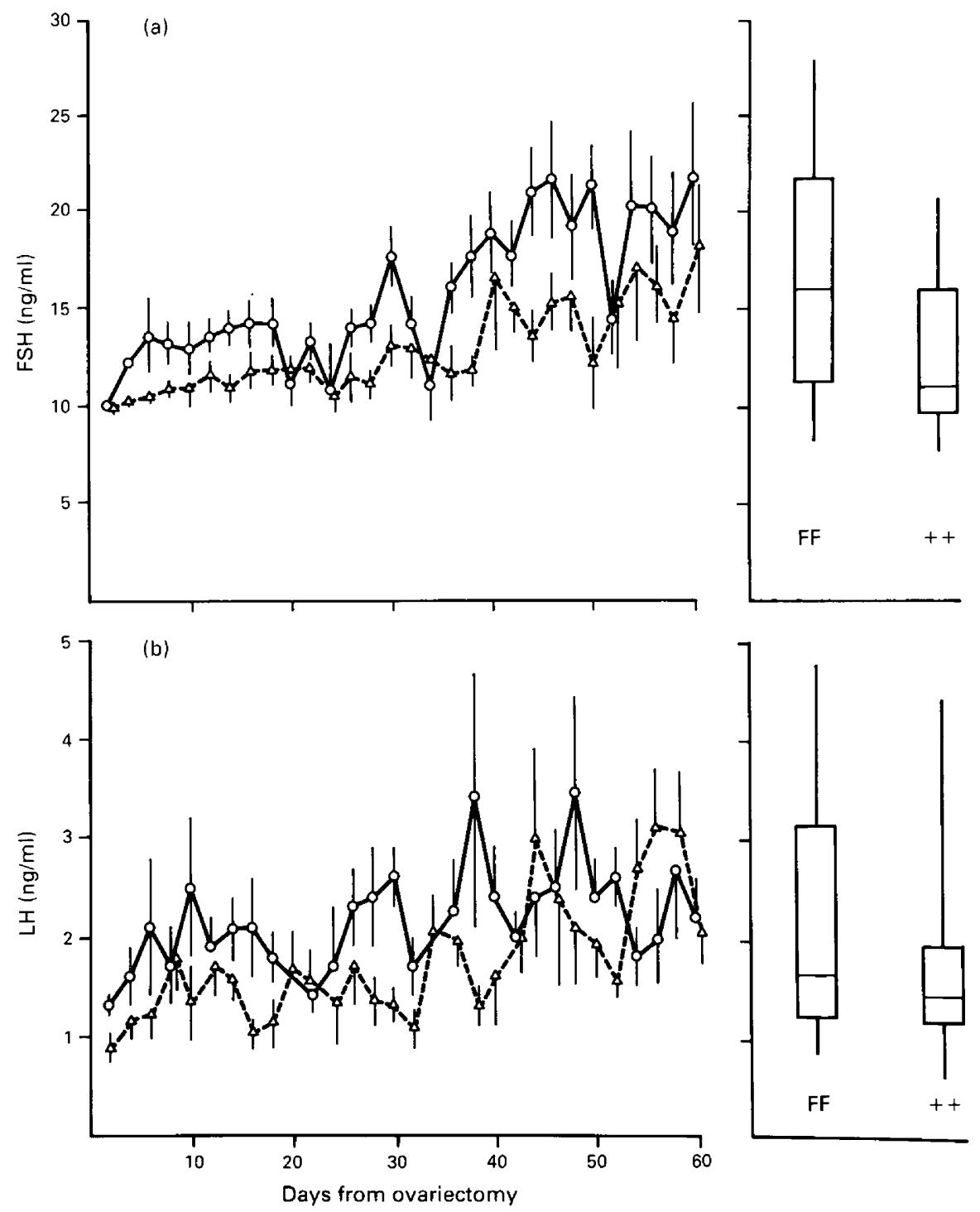

Fig. 3. Changes in the plasma concentrations of FSH (a) and LH (b) once every second day from Day 2 until Day 60 after ovariectomy in FF, $(O-O)$ and $++(\triangle-\cdots-\triangle)$ Booroola ewes. Values are means \pm s.e.m. for 21 ewes/genotype. Also shown are the box and whisker plots of the mean FSH (a) and LH (b) data for each ewe averaged over all times with respect to genotype. The extreme ends of the vertical (whisker) lines represent the maximum and minimum values. The upper and lower horizontal lines of the box refer to the upper and lower quartiles and the lines through the box represent the median values.

\section{Discussion}

The important finding from this study is that the plasma concentrations of FSH and LH in Booroola ewes are more often higher in those of the FF genotype than in the ++ genotype after ovariectomy. However, statistically significantly differences between the genotypes after ovariectomy were rarely observed when the daily mean values were compared (i.e. Exp. 1 or 2) or even 
Table 1. Characteristics of plasma LH concentrations in ovariectomized Booroola ewes which were homozygous $(\mathrm{FF})$ or non-carriers $(++)$ with respect to the F-gene

\begin{tabular}{|c|c|c|c|c|c|}
\hline $\begin{array}{l}\text { Genotype } \\
\text { (no. of ewes) }\end{array}$ & $\begin{array}{l}\text { Mean } \\
(\mathrm{ng} / \mathrm{ml})\end{array}$ & $\begin{array}{c}\text { Smoothed } \\
\text { mean } \\
(\mathrm{ng} / \mathrm{ml})\end{array}$ & $\begin{array}{l}\text { No. of peaks } \\
\text { per } 12 \mathrm{~h}\end{array}$ & $\begin{array}{l}\text { LH peak } \\
\text { amplitude } \\
(\mathrm{ng} / \mathrm{ml})\end{array}$ & $\begin{array}{c}\text { No. of } \\
\text { days after } \\
\text { ovariectomy }\end{array}$ \\
\hline $\begin{array}{l}\text { FF } \\
(21)\end{array}$ & $\begin{aligned} & 3 \cdot 0^{\mathrm{a}} \\
\pm & 0 \cdot 3\end{aligned}$ & $\begin{aligned} & 2 \cdot 8^{a} \\
\pm & 0 \cdot 3\end{aligned}$ & $\begin{array}{r}9.6^{\mathrm{a}} \\
\pm 0.7\end{array}$ & $\begin{array}{r}2 \cdot 6^{a} \\
+0.3\end{array}$ & $\begin{array}{l}32^{a} \\
\pm 1\end{array}$ \\
\hline $\begin{array}{l}++ \\
(21)\end{array}$ & $\begin{aligned} & 2 \cdot 2^{\mathrm{a}} \\
\pm & 0 \cdot 3\end{aligned}$ & $\begin{aligned} & 2 \cdot 1^{\mathrm{b}} \\
\pm & 0 \cdot 2\end{aligned}$ & $\begin{array}{r}8 \cdot 0^{a} \\
\pm 0.4\end{array}$ & $\begin{aligned} & 1.5^{\mathrm{c}} \\
\pm & 0.2\end{aligned}$ & $\begin{array}{l}33^{\mathrm{a}} \\
\pm 1\end{array}$ \\
\hline
\end{tabular}

Values are means \pm s.e.m

Values in columns sharing a common superscript are not different from one another: a $v s$, $P<0.05 ;$ a vs c $P<0.025$ (Students's $t$ test).

when the mean values over all times (e.g. LH and FSH in Exp. 1 or LH in Exp. 2) were compared. The differences were most obvious in the proportions (i.e. frequency) of higher FSH and $\mathrm{LH}$ values in FF compared to ++ ewes. Moreover it was evident that most, if not all, of the ewes contributed to the frequency of higher FSH and LH values over time after ovariectomy since the frequency of high values could not be attributed to 1 or 2 outlier animals (Figs 2 and 3) and since the FSH or LH concentrations in any one ewe on any one day were not necessarily correlated with the concentrations on any previous day. These small and subtle differences in the plasma concentrations of FSH and LH between the genotypes in the ovariectomized ewes are similar in magnitude to those reported in a previous study with intact Booroola ewes (McNatty et al., 1987).

The variances in the FSH and LH values in FF ewes were approximately 2-2.5 times those in ++ ewes. The pattern of pituitary secretion of FSH is not understood in sheep. In large part this has been due to the long half-life of clearance $\left(t_{1}\right)$ of FSH in intact (i.e. $\sim 110 \mathrm{~min}$ ) and ovariectomized (i.e. $\sim 1100 \mathrm{~min}$ ) ewes (Akbar et al., 1973; Fry et al., 1987). However, as the $t_{\frac{1}{2}}$ of FSH does not differ between the Booroola genotypes and since the various forms of FSH in Booroola are similar to those in non-Booroola Merinos (Robertson et al., 1984), the higher variance associated with the plasma FSH concentrations in FF ewes could indicate a more variable pattern of secretion than in ++ ewes. This is clearly the case for LH. For example, in the ovariectomized Booroola ewes, the LH peak amplitudes but not peak frequencies were significantly higher in FF than in ++ ewes which is similar to that found for intact Booroola ewes (McNatty et al., 1987). The finding that the F gene-specific effect on plasma LH concentration is associated with $\mathrm{LH}$ amplitude but not frequency may explain, at least in part, why gene-specific differences in plasma LH concentration are not always observed. For example, LH peak frequency is influenced by steroids (e.g. progesterone) as well as photoperiod (Goodman \& Karsch, 1981) and LH peak amplitude is also influenced (i.e. independently of genotype) by steroids (e.g. oestradiol; Goodman \& Karsch, 1981) and also by stress (Rasmussen \& Malven, 1983). Therefore, if the F gene is influencing only one component of the hypothalamic-pituitary system that controls gonadotrophin secretion then often its influence may be masked by these other factors. In turn, this may explain why the ovulation rate in FF and F + ewes is so often variable (i.e. between 2 and 12).

The effect of ovariectomy on the plasma concentrations of FSH and LH was biphasic. There was a rapid and relatively linear increase in FSH $(\sim 10$-fold $)$ and $\mathrm{LH}(\sim 3$-fold $)$ concentration, with both beginning to rise consistently some 3-4 h after ovariectomy. The effects of anaesthesia or surgical stress on the timing of the increase in gonadotrophin concentration are unknown but some effect cannot be ruled out. However, the initial rapid increase in FSH and LH concentrations continued for some 6 and 12 days respectively. Thereafter, for the next $50+$ days, the concentrations of both gonadotrophins increased only 2-fold with this increase being gradual and fluctuating. The initial rapid rise in gonadotrophin concentration is most likely to be due to the release 
from the negative feedback effects of ovarian hormones with perhaps some effects from the surgical procedure, whereas the second-phase gradual increase in concentration is more likely to be due to alterations in the chemical compositions of FSH and LH (Peckham \& Knobil, 1976a,b; Weick, 1977; Montgomery et al., 1984; Fry et al., 1987).

Collectively, the evidence from the present study that ovariectomized FF ewes more frequently have higher plasma concentrations of FSH and $\mathrm{LH}$ than do ++ ewes suggests that the principal site(s) of $\mathrm{F}$ gene expression is independent of ovarian hormones and may not be in the gonad. Nevertheless, Fry et al. (1988) have shown that the ovaries of hypophysectomized Booroola F+ ewes are more responsive to PMSG than those of ++ ewes some 6 weeks after hypophysectomy, thereby suggesting that the ovary cannot be ruled out as a major site of $F$ gene expression. However, it is possible that these ovarian differences are a legacy of previous differences in gonadotrophin concentration. For example, we have previously shown significant $F$ gene-specific differences in the morphological and functional status of preantral and early antral follicles in Booroola ewes (McNatty et al., 1986; Smith \& McNatty, 1988). It remains to be determined whether a hypothalamic-pituitary-mediated difference in gonadotrophin secretion can influence follicle maturation very early in development and it is still possible that $F$ gene expression occurs both within and outside the ovary.

We thank the National Hormone and Pituitary Program and NIDDK, Bethesda, MD, USA, for supplying the ovine FSH assay kit and ovine LH standards; our colleages at the Invermay Agricultural Research Centre, Mosgiel, NZ, and especially Mr G. Davis for supplying the Booroola ewes and the lifetime reproductive records of these animals; Ms S. Forbes for statistical advice; Dr D. Thurley, Dr P. Truman, Mr S. Lun, Mrs J. McDiarmid and Mr P. Smith for assistance with surgery, blood sampling and animal care; and Mrs P. Cattermole for typing the manuscript.

\section{References}

Akbar, A.M., Nett, T.M. \& Niswender, G.D. (1973) Metabolic clearance and secretion rates of gonadotrophins at different stages of the estrous cycle in ewes. Endocrinology 94, 1318-1328.

Bindon, B.M. (1984) Reproductive biology of the Booroola Merino sheep. Aust. J. biol. Sci. 37, 163-189.

Conover, W.J. (1971) Practical Nonparametric Statistics, 2nd edn, pp. 171-178. John Wiley \& Sons, New York.

Davis, G.H., Montgomery, G.W., Allison, A.J. \& Kelly, R.W. (1982) Segregation of a major gene influencing fecundity in progeny of Booroola sheep. N.Z, J. agric. Res. 25, 525-529.

Fry, R.C., Cahill, L.P., Cummins, J.T., Bindon, B.M., Piper, L.R. \& Clarke, I.J. (1987) The half-life of follicle-stimulating hormone in ovary-intact and ovariectomized Booroola and control Merino ewes. J. Reprod. Fert. 81, 611-615.

Fry, R.C., Clarke, I.J., Cummins, J.T., Bindon, B.M., Piper, L.R. \& Cahill, L.P. (1988) Induction of ovulation in chronically hypophysectomized Booroola ewes. J. Reprod. Fert. 82, 71 I-715.

Goodman, R.L. \& Karsch, F.J. (1981) The hypothalamic pulse generator: a key determinant of reproductive cycles in sheep. In Biological Clocks in Seasonal Reproductive Cycles, pp. 223-236. Eds B. K. Follett \& D. E. Follett. John Wright \& Sons Ltd, Bristol.
McNatty, K.P. \& Henderson, K.M. (1987) Gonadotrophins, fecundity genes and ovarian follicular function. J. Steroid Biochem. 27, 365-373.

McNatty, K.P., Kieboom, L.E., McDiarmid, J., Heath, D.A. \& Lun, S. (1986) Adenosine cyclic 3',5'-monophosphate and steroid production by small ovarian follicles from Booroola ewes with and without a fecundity gene. J. Reprod. Fert. 76, 471-480.

McNatty, K.P., Hudson, N., Henderson, K.M., Gibb, M., Morrison, L., Ball, K. \& Smith, P. (1987) Differences in gonadotrophin concentrations and pituitary responsiveness to $\mathrm{GnRH}$ between Booroola ewes which were homozygous (FF), heterozygous $(F+)$ and non-carriers $(++)$ of a major gene influencing their ovulation rate. J. Reprod. Fert. 80, 577-588.

Montgomery, G.W., Crosbie, S.F., Martin, M.R.C. \& Pelletier, J. (1984) Changes in the clearance rate of immunoreactive LH after ovariectomy in Ile-deFrance ewes. In Reproduction in Sheep, pp. 23-25. Eds D. R. Lindsay \& D. T. Pearce. Australian Academy of Science, Canberra.

Peckham, W.D. \& Knobil, E. (1976a) Qualitative changes in the pituitary gonadotrophins of the male Rhesus monkey following castration. Endocrinology 98, 1054-1060.

Peckham, W.D. \& Knobil, E. (1976b) The effect of ovariectomy, oestrogen replacement and neuraminidase 
treatment on the properties of adenohypophysial glycoprotein hormones of the Rhesus monkey. Endocrinology 98, 1061-1064.

Rasmussen, D.D. \& Malven, P.V. (1983) Effects of confinement stress on episodic secretion of $\mathbf{L H}$ in ovariectomized sheep. Neuroendocrinology 36, 392-396.

Robertson, D.M., Ellis, S., Foulds, L.M., Findlay, J.K. \& Bindon, B.M. (1984) Pituitary gonadotrophins in Booroola and control Merino sheep. J. Reprod. Fert. 71, 189-197.

Smith, P. \& McNatty, K.P. (1988) F gene-specific differences in ultra-structure of granulosa cells from Booroola ewes which were homozygous (FF) or noncarriers $(++)$ of a fecundity gene (F). Proc. N.Z. Soc. Endocrinology, Abstr. No. 20.
Snedecor, G.W. \& Cochran, W.G. (1980) Statistical Methods, pp. 97-98. The Iowa State University Press, Ames.

Van Look, P.F.A. (1976) Studies on the pathophysiology of gynaecological endocrine disorders. Ph.D. thesis, University of Edinburgh.

Velleman, P.F. \& Hoaglin, D.C. (1981) Applications, Basics and Computing of Exploratory Data Analysis, pp. 67-73. Duxburg Press, Boston.

Weick, R.F. (1977) A comparison of the disappearance rates of luteinizing hormone from intact and ovariectomized rats. Endocrinology 101, 157-161.

Zar, J.H. (1974) Biostatistical Analysis, p. 82. PrenticeHall Inc., Englewood Cliffs.

Received 18 August 1988 